41

\title{
"Like a safe tower on a steady rock". Widows, wives and mothers in the ascetic elites of Late Antiquity ${ }^{1}$
}

\author{
Veronika Wieser
}

\author{
Review article \\ UDK 316.66-055.2“652“
}

\begin{abstract}
In the fourth and fifth centuries, the Roman empire underwent a series of changes that profoundly affected its political, economic, social and cultural organization. The long fourth century saw the growth of Christianity from a minor persecuted movement into the Roman state religion. In the wake of this process and with the generous support of Constantine the Great and his successors, Christian communities flourished throughout the empire. This paper will explore some of the many ways in which women were involved in ascetic Christian life in the late Roman West. It aims to sketch the range of new opportunities that may have followed the conversion to asceticism while also reflecting on the more conventional models of womanhood that were still present. In order to do so, the paper will present four small case studies of women who were partly or loosely associated with each other and who participated in the ascetic networks of the late Roman elite: the prominent example of Melania the Elder and the three lesser known case studies of Therasia, Amanda and Bassula.
\end{abstract}

Keywords: early Christian women, renunciation, ascetic ideals, late Roman Christian society

1 I would like to thank the editors of this volume, as well as Rutger Kramer, Diarmuid Ó Riain and Graeme Ward for their assistance and input. Research for this publication was funded by the SBF Visions of Community (Austrian Science Fund/FWF F42-418). 
At the turn of the fifth century, in the spring of the year 400, Melania the Elder returned to Italy from her sojourn in the Holy Land, where she had spent almost three decades (Paulinus of Nola Ep. 29, 6: 690; Palladius c. 46, 54, 55; Dietz 2005: 107-153; Brown 2012: 273-288; Wilkinson 2012: 166-184). On her way from Naples to Rome, she stopped in Nola at the shrine of the third-century saint, Felix, laden with stories and relics for her friends and family. Paulinus, the munificent patron and later bishop of that town, described her arrival in detail, praising her for her outstanding Christian virtues and piety (Paulinus Ep. 29: 682715; Trout 1999: 198-209; Brown 2012: 273-280). Melania's appearance, dressed as she was in dark old rags, riding a shabby horse, stood in sharp contrast to the splendour displayed by her relatives, all members of the highest Roman nobility, who had assembled to greet and accompany the matriarch after her long absence (Paulinus Ep. 29, 12: 708-710; Trout 1999: 198-209; Salzman 2004: 183-184). Melania's family, clad in richly tailored silken togas and dresses and travelling in gilded coaches, admired her for her very poverty, which they valued more highly than their own conspicuous wealth. They even hoped "to be cleansed of the contagion of their riches", and touched Melania's coarse clothes and "gathered some of the dirt from her cheapest garments and her feet" (Paulinus Ep. 29, 12: 710; Trout 1999: 198-209). Paulinus of Nola's detailed account of this appearance gives some insight into a phenomenon typical of the Late Roman Christian aristocracy.

In the course of the fourth century, Rome's upper class had gradually begun to convert to Christianity, encouraged by the example of Emperor Constantine and the effective policy of his successors that allowed and supported the establishment of churches, martyr-shrines and, later, monastic communities (Salzman 2004: 1-68, 178-199; Cameron 1991; Brown 1996; Veyne 2008). This process was not only spurred by imperial decrees and legislative acts but also by the conversion of noble patrons, like Melania or Paulinus. Their social influence and economic power helped promote Christian ideals. Befitting their high social status, they generously funded churches, gave gifts to bishops and ascetics and alms to the poor (Salzman 2004: 200-219; Hillner 2007: 225-261; Brown 2012: 3$52,72-90)$.

In the middle of the fourth century, ideas about asceticism spread from the eastern part of the Roman Empire and were well received in aristocratic circles in the West. Pilgrims and monks who had visited the early coenobitic communities in the Egyptian desert, which were shaped by the visions of Pachomius and Antony, propagated these ideas of a life of self-abnegation, 


\section{6 |}

poverty and chastity and conveyed them to the West (Dunn 2000: 1-24, 59-81, 82-110; Diem 2013a: 31-42). The hagiographic works of Athanasius of Alexandria, Jerome and Sulpicius Severus further promoted the spread of asceticism and provided literary models for the pursuit of an ascetic life or the foundation of an ascetic community (Brown 2000: 781-810; Leyser 2000; Rapp 2010: 119-130). Interestingly, in the initial phase of asceticism, women from wealthy aristocratic families were the first to embrace these new religious ideals (Salzman 2004: 138177; Brown 1988: 308-312; Cooper 2007: 17-23; Dunn 2007). The wives, widows and daughters of Rome's elite, usually lacking the opportunities to lead active public lives, were susceptible to the new social and intellectual possibilities that the pursuit of an ascetic life could offer. Educated women from senatorial families, such as Paula and her daughters, pursued biblical scholarship, learned Greek or even Hebrew and dedicated themselves to reading and discussing theological treatises (Clark 1981: 240-257; Cloke 1995: 15-33; Cooper 2013: 131154; Brown 2012: 273-288) Christian intellectuals joined their literary circles and in turn inspired and advised these women in pursuing their ascetic goals. The lives of the Helena Augusta, mother of Constantine the Great, Melania the Elder or Marcella, who turned her elegant villa on the Aventine Hill into a monastic enclave for virgins, are salient examples of how Christian ascetic ideals changed the way Roman noblewomen perceived and shaped their religious and social roles. By refuting conventional role models and substituting the traditional cycle of re-marriage and child rearing with lives of demonstrable religious piety, they found a niche for relative social and economic autonomy, mobility and selfdetermination within the otherwise rigid hierarchies of Rome's aristocratic society (Cooper 2013: 131-154; Dunn 2007: 669-690).

After the early death of her husband, probably in 373, Melania, then in her early twenties, would have been expected to re-marry soon. Instead, she left her son Publicola in the care of a trusted guardian and took a ship to the port of Alexandria (Palladius c. 46, 54; Paulinus Ep. 29: 682-715). Palladius, bishop of Helenopolis and her travel companion for some time, wrote in his Historia Lausiaca, a compendium of stories about ascetic saints, that due to her family's concerns Melania had planned her departure discreetly, taking with her only a few loyal servants and those belongings that could be carried easily (Palladius c. 46; Elm 1994: 311-330; Rapp 1999: 279-289). In his account, Paulinus cast Melania's struggle to overcome her family's opposition as a fight against the devil's attempts to "thwart her plan" and used it to show her ascetic inclinations (Paulinus Ep. 29, 6, 10: 690-692, 704-706; Palladius c. 46, 54; Cloke 1995: 36-37). 
In the first months of her pilgrimage to Egypt, Melania travelled to Alexandria and its environs, to the mountain of Nitria and the adjacent deserts, where she visited the numerous anachoretes and "living holy people", who dwelled there in cells or caves (Palladius c. 46; Elm 1994: 253-282, 283-310; Leyerle 1999: 345-378; Wilkinson 2002; Dietz 2005: 107-153). In Jerusalem, at the Mount of Olives, she established a convent for women, where she stayed for almost three decades from 374 to 399 (Palladius c. 46; Brown 2012: 276-277). Melania became an influential part of Jerusalem's Christian community. Together with the scholar and theologian Rufinus of Aquileia, she led a model life of Christian piety funded by her former wealth and promoted by her social prestige. She took to charity, provided food and shelter to strangers and friends alike, welcomed visitors and pilgrims, supported local churches and engaged in theological debates (Paulinus Ep. 29, 11: 706-708). According to Paulinus, Melania, born to a family of the old senatorial elite, enhanced her aristocratic status by dedicating her life to Christ and thus obtained celestial nobilitas (Paulinus Ep. 29, 7: 692-696; Palladius c. 46; Harries 1984: 55; Cooper 2013: 198).

The decision to lead an ascetic life caused genuine cognitive and practical dilemmas for some Christian aristocrats. Senators like Melania's friend Paulinus or her relative Pammachius struggled to balance their posts and assets with the demands of the ascetic lifestyle they wanted to pursue, namely one based on the renunciation of all worldly things (Harries 1984: 55-56, 62). Studying the Gospels of Luke (Lk 18:18-27) and Matthew (Mt 19:21-26), which address and problematize the topic of wealth, only heightened already existing concerns about the achievement of salvation (Coon 1997: 1-27, 95-119; Brown 2012: 3-30, 72-90; 208-240; 2016: 1-16, 36-50). In Roman intellectual circles, debates about God's grace, original sin and redemption, which came to the fore in the controversy between the monk Pelagius and the theologian Augustine, added questions about salvation to the discourse within the aristocracy over its Christian identity (Brown 2012: 291-307; 2015: 82-114).

Concerns about personal salvation also played an important role in Melania's decision to lead an ascetic life. She and her family held vast possessions scattered throughout the Roman Empire (Harper 2015: 43-61). However, it became more difficult to protect this wealth in the military crisis of the first decade of the fifth century. In the Empire's west, the provinces in Spain, Gaul, the Balkans and even Italy, the conflicts and wars waged by the Roman army and barbarian troops (particularly since the 370s) created an atmosphere of instability and uncertainty (Pohl 2002: 13-39, 49-57; Halsall 2007: 163-217; 


\section{8|}

Brown 2012: 72-90, 291-307). Against the backdrop of these political developments, Melania was convinced she was experiencing not only the final days of the Empire, but also the last age of the world, which was drawing to its close (Palladius c. 54, 7). By disposing of her fortune, Melania hoped to gain something more valuable than her vast, but transient possessions: namely, eternal spiritual wealth and a "treasure in heaven" (Lk 18:22, Mt 19:21) (Harries 1984: 58-60; Brown 2012: 291-307).

Two years before the sack of Rome in August 410 (Halsall 2007: 214-217), Melania travelled there from Caesarea with an important mission. She had heard that her namesake and granddaughter, whose early devotion to ascetic ideals had been spurred by tragic personal loss, wanted to follow her example (Palladius c. 54,5). Melania the Younger had convinced her husband Pinianus to embrace asceticism. They decided to live like sister and brother, not only rejecting conventional marriage roles but also the enormous wealth both had accumulated as a result of their marriage (Gerontius c. 1-9; Harries 1984: 56). Her grandmother Melania encouraged them in their endeavours and persuaded them to leave Rome for their estate in Sicily. The reason for their departure can partly be found in the desire to lead an ascetic, contemplative life away from worldly turmoil and partly in to their fear of the dangers posed by Alaric's approaching army (Brown 2012: 294-300). Whereas Melania's decision roughly thirty years prior had been met with the family's protests, her granddaughter's decision, especially her rapid liquidation of her estates and slaves, posed an economic and social problem and became a matter of the highest political interest (Gerontius c. 10-14; Cloke 1995: 36-37; Clark 1986: 167-182; Brown 2012:291-307). Also, in the course of this conflict, an existing discrepancy between the social responsibility of the ruling class in adverse times and the individual's pursuit of ascetic ideals became more lucid.

In the Christianization of Rome's elite, religious and social aspects as well as political events contributed to the development of new ways of identification for aristocratic women, especially in the beginning. Because of their economic power and social prestige, these women were able to redefine their social roles through their religious aspirations. Wealth not only played an important role in ascetic narratives as something that had to be overcome and renounced, rather it also allowed aristocratic women to lead ascetic lives in the first place and shape them according to their own ideas (Harries 1984; Salzman 2004: 138-177; Cooper 2013: 191-224). The hagiographic accounts of Melania and her granddaughter contributed to the recognition of their outstanding virtue, to the promotion of 
their saintly status and, over the long term, to the status of their respective communities. Moreover, these accounts and their narrative strategies shaped the specific understanding and images of pious and chaste women within Christian ascetic communities (Coon 1997: 95-119). Another ideal among Rome's Christian elite emerged hand-in-hand with the spread of asceticism which was also, like the debates about poverty and wealth, tied to the question of salvation: virginity (Brown 1988: 33-64; Elm 1994: 25-59; Cooper 1996: 1-19). For her thirteenth birthday, Paula's daughter Eustochium was presented with a letter from Jerome, which later became a model text on the topic of virginity (Jerome Ep. 22: 143-211; Brown 1988: 366-386; Cooper 2013: 192-212). He eloquently encouraged her to remain a virgin and to lead a secluded life of pious study. To explain the spiritual merits and glory that a chaste life could offer to a young girl, he used the vivid examples of the Song of Songs and the story of Martha and Mary (Lk 10:38-42) from the Old and the New Testaments. In this context, one aspect seems to be particularly interesting: whereas Eustochium should remain chaste in the present life, she was meant to become a bride of Christ in Heaven (Jerome Ep. 22, 25. 26. 36. 41). Thus, although Jerome's suggestion that a young woman should stay a virgin was a provocative idea, especially in Roman aristocratic circles, it nonetheless perpetuated conventional gender roles. Marriage seemed to remain the lot of every woman. The idealized images of pious and chaste women displayed by many Christian writers were socially less progressive than they sometimes appeared to be (Coon 1997: 71-94; Cooper 2013: 192-212; Diem 2013b: 432-446; Elliott 2013: 21-35).

In the later phase of the spread of asceticism, from the 390s onwards, these outstanding examples of Paula or Melania were joined by numerous male converts who, like Paulinus of Nola, exchanged their careers in imperial administration and their wealth for a life "in Christ". Similar to their female predecessors, they often ended up establishing their own religious communities, many of them on their own estates (Salzman 2004: 69-137; Alciati 2011: 85-98). However, some of the most renowned ascetic communities of Late Antiquity were managed by "husband-and-wife-teams" or by (spiritual) brother-and-sister enterprises working closely together and sharing the same spiritual values (Salzman 2004: 151, n. 56; Elliott 1993: 52-55). The following three case studies of Therasia, Bassula and Amanda may not be as well-known as the prominent examples of Melania the Elder and Rufinus or Paula and Jerome as duos of female ascetics and male scholars, or Macrina the Younger and her brothers and Monica and her son Augustine. However, they may offer some complementary 
perspectives to the outstanding examples of female renunciation. Although the information on the lives of these women comes mainly via the descriptions of male conversions and is thus fragmentary, they nevertheless provide valuable additional information about the many different ways women could pursue an ascetic lifestyle or participate in an ascetic community.

In 395, Melania's friend Paulinus, a scholarly Christian senator who was born into one of the Empire's wealthiest families, established an ascetic community at the shrine of the town's saint, Felix (Trout 1999: 1-52; Van Dam 1999: 638-639; Mratschek 2002: 49-78; Brown 2012:273-280). Paulinus had renounced his secular past and sold all of their property. He was the first Christian senator to do so and his conversion was a "spectacular gesture" (Fontaine 1972: 580). From the beginning of his ascetic career onwards, Therasia, a rich Spanish heiress, played an important role in it. Not only was she influential on Paulinus' conversion to asceticism according to the admittedly elusive remark of one of his oldest friends, Ausonius (Ausonius Ep. 22, 31; PLRE 1971: 909; Mratschek 2002: 58-60; Salzman 2004: 88), but she also became an important part in the newly founded ascetic community in Nola, where she lived alongside Paulinus as his fellow servant of Christ.

During his subsequent, over thirty years of residency in Nola, Paulinus became an essential part of the elite ecclesiastical circles of the Late Roman West, engaging in construction projects at the site of Felix's shrine both for the benefit of the town and for his own salvation (Trout 1999: 104-132 Lehmann 2004). His messengers travelled from Nola to Gaul, Spain and the North African provinces, and to Dacia and Palestine in the eastern part of the Empire, carrying his letters and gifts to bishops and fellow ascetics, Christian intellectuals and aristocrats, establishing new acquaintances, confirming old friendships or undertaking diplomatic missions (Mratschek 2002: 185-396, 487-591; 2010: 325350). While there is hardly any information about Therasia's life in the newlyestablished monastery (monasterium or fraternitas monacha, Paulinus Ep. 5, 15 : 190 and Ep. 23, 8: 496) at Nola, she became more visible in the correspondence of Paulinus. A total of 51 of the letters of Paulinus are still extant. Of these, eleven were sent by the couple together and address their friends in the praescriptio in a joint authorial voice: Paulinus et Therasia peccatores (Skeb 1998: 73-108). Moreover, both of them were also named in the adscriptio of the responses to these letters. Their letters were sent to the distinguished bishops and theologians Augustine of Hippo (Ep. 4, 6, 45) and Alypius of Thagaste (Ep. 3), as well as to members of their network in North Africa, such as Romanianus (Ep. 7), a relative 
of Alypius and a wealthy citizen of Carthage. They covered topics ranging from the exchange of gifts and recommendations of important books, such as the works of Eusebius, to news about mutual acquaintances and friends, such as Melania the Elder and the death of her son or Augustine's consecration as bishop. Paulinus had established contact with Augustine shortly after his conversion to an ascetic lifestyle. Their correspondence began with an introductory letter from Paulinus to Augustine (Ep. 4) and was followed by a letter about the establishment of the community in Nola (Paulinus Ep. 6; Trout 1999: 202-206; Mratschek 2002: 473-485). Henceforth, Paulinus and Augustine wrote to each other more or less annually for the next 25 years. Therasia was a participant in this correspondence from the beginning, even though she was not named in each of their letters. While it is impossible to tell whether the letters of Paulinus and Therasia were indeed composed by both of them together, letters like these signed by two persons and/or addressed to two persons at least point to a shared interest, a common topic, or to a matter of importance to both of them (Skeb 1998: 99-109; Mratschek 2002: 334-336). Given the fact that these joint letters by a husband and wife are rare, it is worthwhile examine them more closely.

After his conversion, Paulinus' links to his homeland, to Gaul, to fellow bishops in Lyon, Bordeaux or Lérins and to his friends Delphidius, Amandus and Sulpicius Severus remained valuable to him. Therasia did not participate in these contacts as much as she did in the communication with Augustine and Alypius. However, if a new contact was established or if an old one was revived after a longer interruption, it was usual for the husband, Paulinus, to write the letter alone or that the letter was addressed only to him (Mratschek 2002: 335-336). This might have been the case with the letters to Gaul. The letters jointly authored by Paulinus and Therasia were sent to people in Gaul they both would have known before they renounced the world, such as Sulpicius Severus (Ep. 24), Sanctus and Amandus (Ep. 40) and Desiderius (Ep. 43) or, similar to the letters to Alypius and Augustine, with whom they had become acquainted together afterwards, such as, for instance, Sebastianus (Ep. 26) or Aper and Amanda (Ep. 39). After their conversion, Paulinus and Therasia maintained most of their previous social and intellectual circle and even expanded it. Although it is difficult to draw conclusions about Therasia's actual involvement based on the inclusion of her name in the address, it nevertheless highlights her participation in Paulinus' networks as his "sister in Christ" and as a member of the monastic community in Nola. 
We can find more information about a wife's possible role in an ascetic community by closely examining the correspondence between Paulinus and Aper, a lawyer and former provincial proconsul in southern Gaul, who had decided to renounce his wealth and his political career for a "life in Christ" following Paulinus' example (Paulinus Ep. 38, 39 and 44; Skeb 1998: 85-86; Trout 1999: 199). Aper had apparently been ordained as a priest or bishop (sacerdos), and then faced the challenge of organizing the financial responsibilities of his position, such as the management of his estate and family properties (Mathisen 1991: 366; Salzman 2004: 15). In his letters, two of which were addressed to Aper and his wife Amanda and sent from Paulinus and Therasia, Paulinus offered spiritual as well as practical advice (Paulinus Ep. 38, 10: 874). This mutual address makes perfect sense insofar as Amanda played an important part in Aper's decision, but contrary to the examples of Therasia or Pinianus, she was not supposed to follow her spouse's ascetic example. On the contrary, she was expected to take over all worldly burdens on his behalf, which included the management of the family's estates. In doing so, she would enable Aper to pursue exclusively spiritual matters and deal with "heavenly" cares while she bore the worldly ones (saeculi curas, Paulinus Ep. 44, 4: 964). Although Amanda, according to Paulinus, may have preferred to lead a life of abnegation, she chose to face "the world's necessities", "like a safe tower on a steady rock [she] would defy the tempests" (Paulinus Ep. 44, 4: 962-968; Elliott 1993: 53). Nevertheless, Amanda would be as blessed as her husband but for different reasons, because she prioritized her husband's spiritual welfare over her own, and supported him in his ascetic endeavours: Benedicta haec inter mulieres et hac quoque devotione fidelis et acceptissima domino, qua se necessitatibus saeculi pro te velut quaedam procellis in immobili scopulo stabilita turris opposuit (Paulinus Ep. 44, 4: 962).

Similar perspectives on the administrative or organisational role of women in acetic communities (can be found in the correspondence between Paulinus' friend Sulpicius Severus, an Aquitanian scholar and ascetic, best known for his Life of Saint Martin, and his mother-in-law Bassula (Chadwick 1955: 89121). Sulpicius Severus had concluded a prosperous career as a lawyer, sold off his lands and founded a small Christian enclave on his former estate of Primuliacum, near the city of Toulouse (Stancliffe 1983: 15-19, 30-38; Alciati 2011). His decision to lead a life dedicated wholly to Christ was influenced not only by Martin of Tours and Paulinus, for his mother-in-law, Bassula, a pious woman, also played a vital role. Paulinus described her as their "spiritual parent and co-heiress in Christ" (sanctam parentem nostram, matrem in Christo 
coheredem, Paulinus Ep. 5, 19: 196, 198). His efforts to embark upon an ascetic life seem to have brought Sulpicius Severus closer to Bassula, whereas at the same time, in the course of selling his possessions a disagreement may have arose with his own father, whom he left "alone on the rocking boat of life, entangled in his properties like in a net" (Paulinus Ep. 5, 6: 182).

Unfortunately, the extent to which Bassula herself embraced an ascetic lifestyle and whether she perhaps played a similar role in the establishment of the monastery at Primuliacum as Therasia did at Nola (Stancliffe 1983: 31, n. 4) remains unclear. She may have converted to asceticism at around the same time as her son-in-law, but this matter remains obscure (Stancliffe 1983: 17, 30-31). What we do know is that the community built by Sulpicius in Primuliacum and its sustenance benefitted from Bassula's involvement. First, it seems that she, coming as she did from a senatorial family, supported him financially. Sulpicius Severus had enhanced his wealth by marrying Bassula's daughter, whose death preceded his conversion (Paulinus Ep. 5, 5: 176). It is likely that after he had renounced his career and his property, it was partly his own wealth and partly Bassula's that sustained him with the funds he needed to realize his ascetic vision, as well as the ambitious renovation and construction projects at his estate, where he added a second basilica to the family's previous one and connected them with a baptistery within a few years (Paulinus Ep. 31: 728-744; Ep. 32: 746802; Stancliffe 1983: 34-36; Alciati 2011: 250). Although we only know a few details about how Sulpicius managed his financial affairs, it is at least clear that Bassula contributed by paying his stenographers and secretaries (Sulpicius Severus Ep. 3: 144-163).

In general, information on how the ascetic community in Primuliacum was organized is poor, and is derived mainly from Paulinus' letters and Sulpicius' fictionalized depiction in his Dialogues. While it is difficult to know to what extent the social organization of the community differed from that of a typical Late Roman country estate, we can safely assume that, compared to its model, Martin's ideal community in Marmoutier, life in Primuliacum was less contemplative and strict, and more cosmopolitan and worldly (Stancliffe 1983: 3, 30-38; Burrus 1995: 141-145, 158-159; Alciati 2013). However, no female residents or fellow ascetics are explicitly mentioned in the works and letters of Sulpicius, though women may have belonged to the community. Bassula could have participated in its daily routines, although whether or not she actually lived at Primuliacum may not simply be assumed (Burrus 1995: 142). She may have 
just as easily resided somewhere nearby when she was not travelling to Trier, where she had a residence or property.

In this situation, with Sulpicius at home in Primuliacum and Bassula in Trier, a conflict emerged. Bassula was not only intensely interested in Sulpicius' literary activities, for she also wanted to keep abreast of events in the religious community in Aquitaine, which at that time had learned of the death of Martin, the bishop of Tours, in 397 (Stancliffe 1983: 71-73). His death marked the beginning of struggles over his legacy. Having already established himself as the saint's biographer in life, Sulpicius Severus wanted to become the authoritative voice upon Martin's death as well (Van Dam 1993: 13-28; Yuzwa 2014: 329-350; Kramer, Wieser, forthcoming). In order to do so, he wrote a letter to the deacon Aurelius, in which he skilfully displayed the information he had obtained about the bishop's death. However, he later accused his mother-in-law of acquiring and then disseminating the letter, although it was meant to be private and not yet published (Sulpicius Severus Ep. 3, 144-148). Moreover, he claimed that she was eager to see everything he had written and had not left a single page, sheet or letter unread at his place. But how would Bassula have managed to do that, being far away in Trier? Evidently, Sulpicius Severus believed she had spies, namely his secretaries, who were only in his service because of her generosity and who were therefore more loyal to her than to him. Sulpicius Severus nonetheless ended his letter to Bassula on a conciliatory note: if she promised not to read this letter to anybody else, he would share his knowledge with her. He did so, in detail, using the letter as a both private and public platform to present his interpretation of Martin's death and funeral as well as showing that Bassula was an important member of his ascetic community (Ebbeler 2012: 21; Yuzwa 2014; Kramer, Wieser, forthcoming).

A final letter should be mentioned, which was sent to Primuliacum along with a precious gift. Paulinus of Nola forwarded a tiny sliver of the True Cross to Sulpicius Severus. It was part of a gift from Melania the Elder, who had brought it back from Palestine (Paulinus Ep. 31: 728-744; Trout 1999: 239; Mratschek 2002: 435-437). The sliver, held in a golden vial, was to be enshrined in the new basilica that Sulpicius Severus had built in Primuliacum. In the praescriptio of the letter, only Paulinus is mentioned explicitly, but based on its content Therasia was the one who gave the gift to Bassula: "Quod nobis bonum benedicta Melanius ab Hierusalem munere sancti inde episcopi lohannis adtulit, hoc specialiter sorori nostrae venerabili Bassuale misit conserva communis; sed quod alteri vestrum datur utriusque vestrum est, quia in utroque vestrum una ratio manet et sexum 
evacuat fides, qua in virum perfectum ambo concurritis" (Paulinus Ep. 31, 1: 729730). Paulinus explained that as they both shared the same spiritual values, it was as if it was given not only to one but to both, Bassula and Sulpicius Severus. In this passage, it becomes more evident that Sulpicius Severus and his mother-inlaw shared a religious calling and a mutual interest in the new basilica at Primuliacum, in which Paulinus and Therasia were also represented thanks to their gift (Paulinus Ep. 32, 1-10: 746-770). The letter also contains another perspective on female asceticism: It was through their faith, as Paulinus wrote, that Sulpicius and Bassula would be able to reach a man's perfection (in virum perfectum ambo concurritis), and would render gender irrelevant (sexum evacuat fides, Paulinus Ep. 31, 1: 728-730).

Generally, when looking at accounts of conversion from the late fourth century, and especially decisions to lead an ascetic life, there seems to be a strong resemblance between the biographies of holy men and holy women, who were well-educated, shared a similar social background and then engaged themselves in many different ways inside flourishing Christian communities (Salzman 2004: 69-177). There are also similarities in the precipitating events and reasoning behind such a radical change from lifestyles that appeared to have been prosperous and fortunate. However, especially for women, the difficulty in culturally accommodating these new possibilities of social and religious selfdefinition within existing models of gender roles, family traditions and expectations remained.

The presented case studies of aristocratic and wealthy women like Melania, Therasia, Amanda and Bassula might not be reflective of female asceticism in general, but rather only of the ascetic aspirations of the Roman elite. Their ascetic communities in Jerusalem, Primuliacum and Nola were not only formed around a certain spiritual attitude but also around the personal relationships of its members, and they were embedded in shared elitist social background. In these communities, the authority and participation of women such as Therasia or Bassula were acknowledged by their families and friends, like Sulpicius or Paulinus for example, and by members of their networks, such as Alypius and Augustine. Those who shared that attitude and the common social patterns could therefore participate as partners. Some of these women, like Bassula, may have also been responsible for the maintenance of a community, even though it is very challenging and sometimes hardly possible to discern female participation in the extant source material. However, it is important to stress that these women are only known to us because they were part of a 
smaller or larger community that defined itself primarily as being ascetic/Christian in a non-ascetic/Christian world and it was through their various choices to pursue ascetic ideals that they became more visible.

\section{Bibliography}

\section{Primary Sources}

\section{AUSONIUS}

Ausonius, Epistulae, in: The Works of Ausonius (ed. R.P.H. Green), Oxford 1991.

\section{GERONTIUS}

Gerontius, Vita Melaniae Iunioris, in: Vie de Sainte Mélanie. Vol. 90 of

Sources Chrétiennes (ed. Denys Gorce), Paris 1962.

JEROME

Jerome, Epistula 22, in: S. Eusebii Hieronymi Opera 1, Epistulae 1, (ed. Isidor Hilberg), Vol. 54 of CSEL, Berlin et al. 1996 [1910], 143-211.

\section{PALLADIUS}

Palladius, Historia Lausiaca, in: Patristische Studien 51, (ed. Adelheid Wellhausen), Berlin et al. 2003.

PAULINUS

Paulinus von Nola, Epistulae, in: Fontes Christiani Vol. 25, 1-3, (ed. Matthias Skeb), Freiburg et al. 1998.

\section{SULPICIUS SEVERUS}

Sulpicius Severus, Vita sancti Martini. Epistulae (ed. Kurt Smolak), Eisenstadt 1997.

\section{Secondary Sources}

ALCIATI 2011

Roberto Alciati, "And the Villa Became a Monastery: Sulpicius Severus' Community of Primuliacum", in: Western Monasticism "ante litteram". The Spaces of Monastic Observance in Late Antiquity and the Early Middle Ages, (ed. Hendrik Dey, et al.), Turnhout 2011, 85-98.

BOWES 2010

Kimberly Diane Bowes, Houses and Society in the Later Roman Empire. London 2010. 
BROWN 1988

Peter Brown, The Body and Society: Men, Women, and Sexual

Renunciation in Early Christianity, New York 1988.

BROWN 1996

Peter Brown, The Rise of Western Christendom. Triumph and Diversity, AD 200-1000, Malden/MA, Oxford 1996.

BROWN 2000

Peter Brown, "Holy Man", in: The Cambridge Ancient History Vol. 14, Late Antiquity: Empire and Successors, A.D. 425-600, (ed. Averil Cameron, Bryan Ward-Perkins, Michael Whitby), Cambridge 2000, 781810.

BROWN 2012

Peter Brown, Through the Eye of a Needle. Wealth, the Fall of Rome, and the Making of Christianity in the West, 350-550 AD, Princeton 2012.

BROWN 2015

Peter Brown, The Ransom of the Soul. Afterlife and Wealth in Early Western Christianity, Cambridge/MA 2015.

BROWN 2016

Peter Brown, Treasure in Heaven: The Holy Poor in Early Christianity, Charlottesville, London 2016.

BURRUS 1995

Virigina Burrus, The Making of a Heretic. Gender, Authority, and the Priscillianist Controversy. Berkeley 1995.

\section{CHADWICK 1955}

Nora Chadwick, Poetry and Letters in Early Christian Gaul, London 1955.

\section{CLARK 1981}

Elizabeth Clark, "Ascetic Renunciation and feminine advancement: A paradox of late ancient Christianity", in: Anglican Theological Review 63, 1981, 240-257.

\section{CLARK 1986}

Elizabeth Clark, "Piety, Propaganda, and Politics in the Life of Melania the Younger". Vol 18/2 of Studia Patristica, Oxford 1986, 167-183. 


\section{CLOKE 1995}

Gilian Cloke, The Female Man of God: Women and Spiritual Power in the Patristic Age, AD 350-450, London et al. 1995.

COON 1997

Linda Coon, Sacred Fictions. Holy Women and Hagiography in Late Antiquity, Philadelphia 1997.

\section{COOPER 1996}

Kate Cooper, The Virgin and the Bride: Idealized Womanhood in Late Antiquity, Cambridge/MA et al. 1996.

\section{COOPER 2007}

Kate Cooper, The Fall of the Roman Household, Cambridge 2007.

COOPER 2013

Kate Cooper, Band of Angels: The Forgotten World of Early Christian Women, Manchester 2013.

DIEM 2013A

Albrecht Diem, „Die Wüste im Kopf. Askese und Sexualität in Spätantike und Frühmittelalter", in: Guter Sex: Moral, Moderne und die katholische Kirche, (ed. Regina Ammicht), Schöningh 2013, 31-42.

DIEM 2013B

Albrecht Diem, "The Gender of the Religious: wo/men and the Invention of monasticism", in: The Oxford Handbook of Women and Gender in Medieval Europe, (ed. Judith Bennett et al.), Oxford 2013, 432-446.

DIETZ 2005

Maribel Dietz, Wandering Monks, Virgins, and Pilgrims. Ascetic Travel in the Medtiterranean World, A.D. 300-800, University Park/PA 2005.

DUNN 2000

Marilyn Dunn, The Emergence of Monasticism. From the Desert Fathers to the Early Middle Ages, Malden/MA 2000.

DUNN 2007

Marilyn Dunn, "Asceticism and monasticism 2: Western", in: The Cambridge History of Christianity vol. 2: Constantine to c. 600 (ed. by Michael Casiday et al.), Cambridge 2007, 669-690. 


\section{ELLIOTT 1993}

Dyan Elliott, Spiritual Marriage: Sexual Abstinence in Medieval Wedlock, Princeton 1993.

\section{EBBELER 2012}

Jennifer Ebeler, Disciplining Christians: Correction and Community in Augustine's Letters. Oxford 2012.

\section{ELLIOTT 2013}

Dyan Elliott, "Gender and the Christian traditions", in: The Oxford Handbook of Women and Gender in Medieval Europ, (ed. Judith Bennett et al.), Oxford Press 2013, 21-35.

\section{ELM 1994}

Susanna Elm, Virgins of God: The Making of Asceticism in Late Antiquity, Oxford 1994.

\section{FONTAINE 1972}

Jacques Fontaine, "Valeurs antiques et valeurs chrétiennes dans la spiritualité des grands propriétaires terriens à la fin du IVe siècle occidental", in: Epektasis. Mélanges patristiques offerts au Cardinal Jean Daniélou, (ed. Fontaine et al.), Paris 1972, 571-595.

HALSALL 2007

Guy Halsall, Barbarian Migrations and the Roman West, 376-568, Cambridge 2007.

\section{HARPER 2016}

Kyle Harper, "Landed Wealth in the Long Term Patterns, Possibilities, Evidence", in: Land and Natural Resources in the Roman World (ed. Paaul Erdkamp et al.), Oxford 2015, 43-61.

\section{HILLNER 2007}

Julia Hillner, "Families, Patronage, and the Titular Churches of Rome, c. 300-c. 600", in: Religion, Dynasty, and Patronage in Early Christian Rome, 300-900, (ed. Kate Cooper, Julia Hillner), Cambridge 2007, 225261.

\section{KRAMER, WIESER forthcoming}

Rutger Kramer, Veronika Wieser, „You Only Die Twice. Abbots between Community and Empire. The Cases of Martin of Tours and Benedict of Amiane," in: Hortus Artium Medievalium, 2017. 


\section{LEHMANN 2004}

Tomas Lehmann, "Paulinus Nolanus und die Basilica Nova in Cimitile/Nola. Studien zu einem zentralen Denkmal der spätantikfrühchristlichen Architektur", in: Spätantike-Frühchristentum-Byzanz. Kunst im ersten Jahrtausend/B: Studien und Perspektiven, 19, Wiesbaden 2004.

\section{LEYERLE 1999}

Blake Leyerle, 'Pilgrims to the Land: Early Christian Perceptions of Galilee', in: Galilee Through the Centuries: Confluence of Cultures, (ed. Eric M. Meyers), Winona Lake, IN 1999, 345-378.

\section{LEYSER 2000}

Conrad Leyser, Authority and Asceticism from Augustine to Gregory the Great, Oxford 2000.

\section{MATHISEN 1991}

Ralph Mathisen, Studies in the History, Literature, and Society of Late Antiquity, Amsterdam 1991.

\section{MRATSCHEK 2002}

Sigrid Mratschek, Der Briefwechsel des Paulinus von Nola. Kommunikation und soziale Kontakte zwischen christlichen Intellektuellen, Göttingen 2002.

POHL 2002

Walter Pohl, Die Völkerwanderung. Eroberung und Integration, Stuttgart et al. 2002.

RAPP 2004

Claudia Rapp, "Palladius, Lausus and the Historia Lausiaca”, in: Novum Millennium. Studies on Byzantine History and Culture (ed. Claudia Sode, Sarolta Takács), Aldershot 1999, 279-289.

RAPP 2010

Claudia Rapp, "The origins of hagiography and the literature of early monasticim: purpose and genre between tradition and innovation", in: Unclassical Traditions Vol. 1: Alternatives to the Classical Past in Late Antiquity, (ed. Chrisopher Kelly, Richard Flower, Michael Stuart Williams), Cambridge 2010, 119-130. 


\section{SALZMAN 2004}

Michele Renee Salzman, The Making of a Christian Aristocracy. Social and Religious Change in the Western Roman Empire, Cambridge/MA 2004.

\section{SKEB 1998}

Matthias Skeb, "Einleitung", in: Paulinus von Nola Briefe (Fontes Christiani 25/2), Freiburg et al. 1998, 9-115.

\section{STANCLIFFE 1983}

Clare Stancliffe, St. Martin and his Hagiographer. History and Miracle in Sulpicius Severus. Oxford 1983.

PLRE

"Therasia", in: The Prosopography of the Later Roman Empire 1: A.D. 260-395, vol. 1 (ed. A.H.M. Jones et al.), Cambridge 1971, 909.

TROUT 1999

Dennis E. Trout, Paulinus of Nola. Life, Letters, and Poems, Berkeley 1999.

\section{VAN DAM 1993}

Raymond Van Dam, Saints and their Miracles in late Antique Gaul. Princeton, Princeton 1993.

\section{VAN DAM 1999}

Raymond Van Dam, "Paulinus", in: Late Antiquity: A Guide to the Postclassical World, (ed. Glen W. Bowersock et al.), Cambridge/MA et al. 1999, 638-639.

VEYNE 2008

Paul Veyne, Als unsere Welt christlich wurde. Aufstieg einer Sekte zur Weltmacht, 312-394, München 2008.

\section{YUZWA 2014}

Zachary Yuzwa, „Reading Genre in Sulpicius Severus' Letters,“ Journal of Late Antiquity, 7/2, 2014, 329-350.

\section{WILKINSON 2012}

Kevin Wilkinson, "The Elder Melania's Missing Decade," Journal of Late Antiquity, 5/1, 2012, 166-184.

\section{WILKINSON 2002}

John Wilkinson, Jerusalem Pilgrims. Before the Crusades, Oxford 2002. 